\title{
Localization of Transforming Growth Factor $\alpha$ and Its Receptor in Gastric Mucosal Cells

\author{
Implications for a Regulatory Role in Acid Secretion and Mucosal Renewal
}

R. D. Beauchamp, ${ }^{\star \ddagger}$ J. A. Barnard,"5 C. M. McCutchen," J. A. Cherner," and R. J. Coffey, Jr.*"

${ }^{*}$ Departments of Cell Biology, ${ }^{\ddagger}$ Surgery, ${ }^{\S}$ Pediatrics, and $"$ Medicine, Vanderbilt University School of Medicine, Nashville, Tennessee 37232

\begin{abstract}
Transforming growth factor $\alpha$ (TGF $\alpha)$ shares with epidermal growth factor (EGF) structural homology (35\%), a common cell-surface membrane receptor (TGF $\alpha /$ EGF receptor), and a nearly identical spectrum of biological activity, including inhibition of gastric acid secretion. Herein, we report expression of TGF $\alpha$ mRNA in normal gastric mucosa of the adult guinea pig, rat, and dog. TGF $\alpha$ mRNA was also detected in matched surgically resected gastric mucosa and adjacent gastric carcinoma from 10 patients, and in gastric mucosa adjacent to a benign ulcer from an additional patient. TGF $\alpha$ protein was quantitated by radioimmunoassay and was present in tumor and adjacent mucosa. TGF $\alpha / E G F$ receptor mRNA was also detected in gastric mucosa from all species studied. Localization of TGF $\alpha$ and TGF $\alpha / E G F$ receptor mRNA expression was examined in samples of unfractionated guinea pig gastric mucosa and from chief cell-enriched and parietal cell-enriched fractions. All samples exhibited TGF $\alpha$ and TGF $\alpha /$ EGF.receptor expression. The TGF $\alpha$ signal was greatest in the parietal cell fraction (5.8-fold increase), but was also enhanced in the chief cell fraction (1.9-fold increase) relative to the unfractionated gastric mucosa. Like TGF $\alpha$ expression, TGF $\alpha /$ EGF receptor mRNA expression was most intense in the parietal cellenriched fraction (7.8-fold increase), but was also increased in the chief cell-enriched fraction (2.7-fold increase) relative to the unfractionated guinea pig gastric mucosa. We conclude that TGF $\alpha$ and TGF $\alpha /$ EGF receptor genes are expressed in normal adult mammalian gastric mucosa. These findings, when interpreted in light of described actions of TGF $\alpha$ and EGF, provide evidence that local production of TGF $\alpha$ could play an important role in the regulation of acid secretion and mucosal renewal in the stomach.
\end{abstract}

\section{Introduction}

Epidermal growth factor (EGF) ${ }^{1}$ and transforming growth factor $\alpha$ (TGF $\alpha)$ are homologous polypeptides $(1,2)$, both of which bind to the EGF receptor (3-5). TGF $\alpha$ was initially postulated to be an embryonic growth factor that was inappropriately expressed in neoplasia (6). More recently, TGF $\alpha$ ex-

Address reprint requests to Dr. Coffey, Jr., Department of Medicine, Gastroenterology Division, Vanderbilt University, Nashville, TN 37232.

Received for publication 8 November 1988 and in revised form 4 May 1989.

1. Abbreviations used in this paper: EGF, epidermal growth factor; TGF $\alpha$, transforming growth factor $\alpha$.

J. Clin. Invest.

(c) The American Society for Clinical Investigation, Inc.

2021-9738/89/09/1017/07 \$2.00

Volume 84, September 1989, 1017-1023 pression has been detected in a number of nontransformed cells and tissues (7-9). The spectrum of biological activity for TGF $\alpha$ and EGF are qualitatively similar, although several quantitative differences have been observed $(10,11)$. All known actions of both ligands appear to be mediated via binding to the TGF $\alpha / E G F$ receptor; no discrete TGF $\alpha$ receptor has been identified (12).

Both EGF and TGF $\alpha$ have been shown to have potent effects on the gastric mucosa, a complex epithelium composed of multiple cell types. Surface epithelial cells, which line the mucosa of all regions of the stomach, secrete mucus and bicarbonate. Parietal cells, which secrete hydrochloric acid, and chief cells, which secrete pepsinogen, are found primarily in gastric glands in the fundus and body. Neuroendocrine cells consist of gastrin-producing G-cells, somatostatin-producing D-cells, enterochromaffin cells and enterochromaffin-like cells; their distribution varies with the particular cell type, e.g., the stomach's G-cells are confined to the antrum (13).

EGF stimulates DNA synthesis in the gastric mucosa of rodents (14-16) and protects against gastric ulcer formation in rats and cats at doses that have no effect on acid secretion (16). Removal of salivary glands (the major intraluminal source of EGF) in rats results in atrophy of gastric mucosa (17) and a delay in healing of gastric and duodenal ulcerations that can be reversed by treating the animals with either oral or parenteral EGF (18). These studies imply an important physiological role for EGF in gastric mucosal growth. Of potential importance in the stomach, both TGF $\alpha$ (19) and EGF (20) are acid stable proteins.

Extracts from human urine have long been known to inhibit gastric acid secretion $(21,22)$. The putative gastric acid inhibitory agent was named urogastrone. Subsequent purification and characterization of human $\operatorname{EGF}(20,21)$ and human $\beta$-urogastrone (24) revealed that they were identical. In conscious dogs, EGF inhibits gastric acid secretion stimulated by pentagastrin, histamine, and urecholine, as well as that stimulated by meal and sham feeding (25). In anesthetized rats, EGF inhibits gastric acid secretion stimulated by carbachol, histamine, and pentagastrin (26). EGF (27) and TGF $\alpha$ (28) inhibit histamine-stimulated gastric acid secretion from isolated guinea pig gastric mucosa when delivered to the serosal, but not luminal surface; intravenous delivery of both ligands inhibits acid secretion in rats (29). In addition to inhibiting acid secretion, EGF inhibits pepsinogen secretion in rabbit gastric mucosa stimulated by agonists that increase intracellular cAMP (30). High affinity TGF $\alpha /$ EGF binding sites have been demonstrated on both fundic and antral gastric glands from the guinea pig (31).

TGF $\alpha$ is no longer regarded simply as an embryonic growth factor that is inappropriately expressed in neoplasia, but also as an integral physiological regulator of growth in normal tissues $(12,32,33)$. In screening gastrointestinal tissues for TGF $\alpha$ expression, we found relatively abundant levels in 
the gastric mucosa. Given the aforementioned effects of TGF $\alpha$ and EGF on gastric mucosal growth, repair, and acid secretion, we examined gastric mucosa from four mammalian species for TGF $\alpha$, EGF, and TGF $\alpha /$ EGF receptor expression and attempted to localize expression to a subpopulation of gastric mucosal cells.

\section{Methods}

Processing of tissue. Gastric mucosa was obtained from normal adult mongrel dogs, guinea pigs, and rats at sacrifice and kidneys were obtained from rats and dogs. Human gastric and kidney samples were obtained fresh from the Department of Surgical Pathology. Human gastric carcinoma and adjacent uninvolved gastric mucosa were also obtained from the Cooperative Human Tissue Network of the $\mathrm{Na}$ tional Cancer Institute and from the Mayo Clinic (Rochester, MN). The gastric mucosa was washed with cold water and then rapidly dissected from the muscularis. The samples were rapidly frozen in liquid nitrogen and stored at $-80^{\circ} \mathrm{C}$ until processing. Human tissue utilization was approved by Vanderbilt University and Mayo Clinic Institutional Review Boards.

Method of obtaining enriched cell fractions. Female guinea pigs (200-250 g), strain 2, were obtained from the National Cancer Institute (Frederick, MD). Enriched populations of guinea pig chief cells and parietal cells were obtained as described previously (34). In brief, the mucosa of gastric fundus and antrum was incubated in standard incubation solution containing $0.1 \%$ collagenase for $30 \mathrm{~min}$ at $37^{\circ} \mathrm{C}$ and gassed with $100 \%$ oxygen. Single cells were formed by incubating with $2 \mathrm{mM}$ EGTA, dispersed by syringe and fractionated on a Percoll density gradient $(d 1.065 \mathrm{~g} / \mathrm{ml})$. At least 300 cells were counted and each cell type was determined as a percentage of the total cell population counted. The cell populations obtained have been characterized previously by Papanicolaou, PAS, and immunofluorescent staining (34).

In agreement with the previous report (34), the least dense fraction (density less than $1.040 \mathrm{~g} / \mathrm{ml}$ ) of guinea pig gastric mucosal cells was enriched with parietal cells, comprising $60-70 \%$ of that fraction's cells. It has previously been shown that this fraction is depleted of chief cells (34). The fractions migrating between 1.060 and $1.080 \mathrm{~g} / \mathrm{ml}$ were highly enriched with chief cells, containing $\sim 95 \%$ chief cells. The yield of cells in these fractions varied among cell preparations, ranging from 1.0-1.5 $\times 10^{7}$ cells per stomach. Chief cells obtained from six stomachs and parietal cells from four stomachs were pooled and stored in guanidinium isothiocyanate buffer at $-80^{\circ} \mathrm{C}$.

RNA extraction and blotting. Total cellular RNA was prepared from excised tissues using a phenol extraction method as described previously (35). Total cellular RNA from enriched cell fractions was prepared by homogenization in $4 \mathrm{M}$ guanidinium isothiocyanate and pelleted through a cesium chloride cushion by ultracentrifugation (36). Polyadenylated (poly A) RNA was isolated with oligo (dT) cellulose (Collaborative Research Inc., Bedford, MA). RNA was electrophoretically separated on a formaldehyde/1.2\% agarose gel (37) and blotted onto nitrocellulose as described (38).

The TGF $\alpha$ clone is a human $1.27-\mathrm{kb}$ cDNA encompassing the entire open reading frame as well as $0.79-\mathrm{kb}$ of flanking $3^{\prime}$ untranslated sequence (2). The TGF $\alpha /$ EGF receptor clone is a human $0.889-\mathrm{kb}$ cDNA that encompasses the COOH-terminal 198 codons plus 290 base pairs of $3^{\prime}$ untranslated cDNA (39). The probes were subcloned into plasmid SP65 and labeled with [ $\alpha-{ }^{32}$ P]UTP as described (40). Hybridization and posthybridization washes were carried out at $65^{\circ} \mathrm{C}$ as previously described (41). A human EGF cDNA probe was kindly provided by Graeme Bell (42), and an Eco RI insert was labeled by a random primer extension method (43). Hybridization and posthybridization washes were carried out at $43^{\circ} \mathrm{C}$. For all of the Northern blots, hybridization with a cDNA probe (1B15) for the constitutively expressed cyclophilin gene (44) demonstrated that the RNA was intact.
RNA was quantitated by ultraviolet spectroscopy at $260 \mathrm{nM}$. Relative loading of lanes and the integrity of RNA was verified by ethidium bromide-stained ribosomal RNA band intensity where precise quantitation was necessary. Laser densitometry was performed for quantitation of $28 \mathrm{~S}$ ribosomal RNA on a photographic negative of gels and for signal intensity on autoradiograms of Northern blots.

Protein extraction for TGF $\alpha$. Extraction of gastric mucosal TGF $\alpha$ protein was performed using a modification of a previously described method (19). One to two grams of previously frozen $\left(-80^{\circ} \mathrm{C}\right)$ human gastric mucosa or carcinoma was homogenized and stirred overnight at $4^{\circ} \mathrm{C}$ in $4 \mathrm{ml} / \mathrm{g}$ of acid-ethanol solution containing $90 \%$ ethanol, $0.2 \mathrm{M}$ $\mathrm{HCl}$, pepstatin $(5 \mu \mathrm{g} / \mathrm{ml})$, leupeptin $(5 \mu \mathrm{g} / \mathrm{ml})$, and PMSF $(0.5 \mathrm{mM})$. The homogenate was clarified by centrifugation and the supernatant stored while the pellet was resuspended and stirred $4 \mathrm{~h}$ at $4^{\circ} \mathrm{C}$ in a second acid-ethanol solution containing $77 \%$ ethanol and $0.2 \mathrm{M} \mathrm{HCl}$, after which the suspension was centrifuged. Both supernatants were then combined, extensively dialyzed using Spectrapor 3 dialysis tubing (3,500 mol wt cut-off) against $0.1 \mathrm{M}$ acetic acid, and lyophilized. Before the TGF $\alpha$ assay, the extracts were resuspended in a minimal volume of $0.15 \mathrm{M} \mathrm{NaCl}-0.1 \mathrm{M}$ acetic acid, centrifuged, adjusted to $\mathrm{pH}$ 7.4 with $1 \mathrm{M}$ Tris and amounts of protein determined by the method of Bradford (Bio-Rad Laboratories, Richmond, CA) (45). Levels of human TGF $\alpha$ were determined using a radioimmunoassay kit (Biotope, Seattle, WA). The polyclonal antibody was raised against recombinant rat TGF $\alpha$, which recognizes human TGF $\alpha$, but does not recognize EGF.

\section{Results}

TGF $\alpha$ mRNA was detected by Northern blot analysis of poly (A) RNA from gastric mucosa of normal adult guinea pig and dog as well as from histologically normal gastric mucosa from a patient with a benign gastric ulcer (Fig. 1). TGF $\alpha$ mRNA was also detected in the gastric mucosa of normal adult rats (data not shown). In the dog, there was relatively more TGF $\alpha$ mRNA expression (approximately fourfold) in the antral mucosa than in the fundic mucosa (Fig. 2). Similar results were obtained from RNA preparations from two separate dogs. These differences in antral and fundic TGF $\alpha$ expression were not observed in the human samples. Relative to the other species, the TGF $\alpha$ transcript was slightly smaller in dog stomach and kidney. The TGF $\alpha$ transcript was not detected in equivalent amounts of poly (A) RNA obtained from canine gastric muscle underlying both fundic and antral mucosa. Four human gastric submucosal samples from two separate patients were examined for TGF $\alpha$ mRNA expression and a faint TGF $\alpha$ signal was detected in a single sample and this detection required a prolonged exposure of the autoradio-

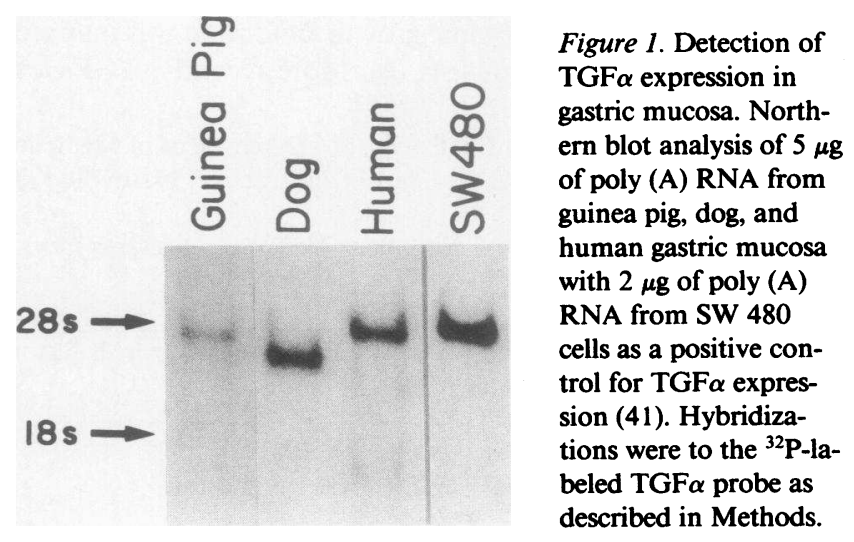




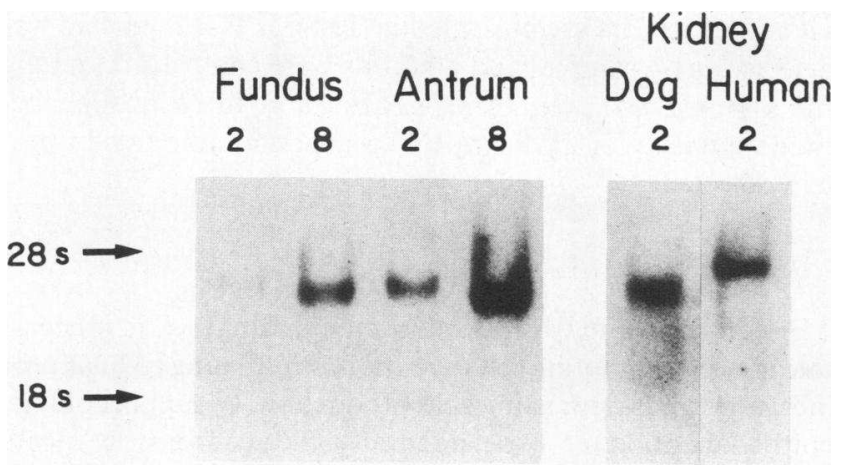

Figure 2. Level of TGF $\alpha$ mRNA expression in dog antral mucosa compared with fundic mucosa. Micrograms of poly (A) RNA per lane are indicated above each lane. Hybridization was to the ${ }^{32} \mathrm{P}$-labeled TGF $\alpha$ probe. Dog and human kidney poly (A) RNA was examined for comparison.

graph. The TGF $\alpha$ transcript was not detectable in the remaining human gastric submucosal samples (data not shown). Thus, in the species examined, TGF $\alpha$ expression is largely localized to the epithelial compartment of the stomach.

The blot depicted in Fig. 2 was also probed with a ${ }^{32} \mathrm{P}$-labeled human EGF cDNA probe (Fig. 3). At a 48-h exposure, the 5.2-kb EGF signal was detected in the dog fundus but not the antrum. This differential localization of EGF within the dog gastric mucosa was confirmed in a second dog. The EGF signals detected at $48 \mathrm{~h}$ in the kidney samples were overexposed relative to those seen in the fundus and antrum. A shorter exposure $(6 \mathrm{~h})$ showed the EGF transcripts in the dog and human kidney samples more clearly (Fig. 3). An EGF transcript has not been detected, even after prolonged exposure, in any gastric mucosal samples from humans, guinea pigs, or rats (data not shown).

Localization of TGF $\alpha$ and TGF $\alpha /$ EGF receptor mRNA expression within the gastric mucosa was determined using

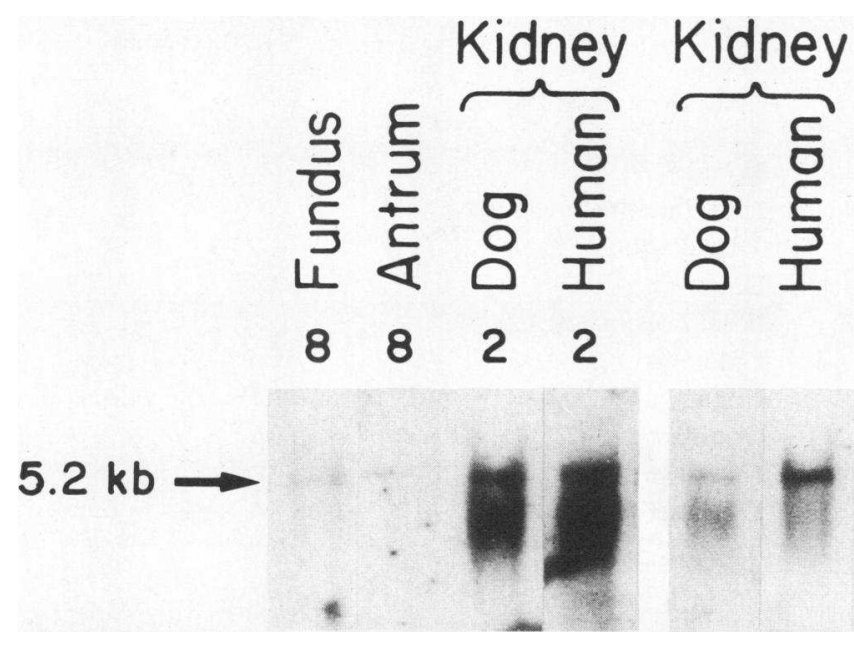

Figure 3. EGF mRNA expression in stomach and kidney. The indicated amounts of poly (A) RNA were hybridized with the ${ }^{32} \mathrm{P}$-labeled EGF cDNA probe as described in Methods. The left four lanes were on a single blot which was exposed to $\mathrm{x}$-ray film for $48 \mathrm{~h}$. The right two lanes are a briefer exposure $(6 \mathrm{~h})$ of the kidney samples. enriched subpopulations of guinea pig gastric mucosal cells that contained $\sim 95 \%$ chief cells, or $\sim 65 \%$ parietal cells. Duplicate gels with $20 \mu \mathrm{g}$ of electrophoretically separated total cellular RNA from nonenriched, chief cell-enriched and parietal cell-enriched fractions were blotted and hybridizations were carried out with the probes for TGF $\alpha$ (Fig. $4 A$ ) and TGF $\alpha /$ EGF receptor (Fig. $4 B$ ). Visual inspection of the ethidium bromide-stained gels under ultraviolet light revealed near-equal RNA loading, and the intensities of the TGF $\alpha$ and TGF $\alpha /$ EGF receptor signals were determined by laser densitometry after normalizing to the intensities of the respective 28S ribosomal RNA bands (data not shown). The TGF $\alpha$ signal was greatest in the parietal cell fraction (5.8-fold increase), but was also enhanced in the chief cell fraction (1.9-fold increase) relative to the unfractionated gastric mucosa (Fig. $4 \mathrm{~A}$ ). The 10-kb TGF $\alpha /$ EGF receptor transcript was observed in all three samples (Fig. 4 B). As with TGF $\alpha$ expression, the TGF $\alpha /$ EGF receptor expression was most intense in the parietal cellenriched fraction (7.8-fold increase), but was also increased in the chief cell-enriched fraction (2.7-fold increase) compared to the unfractionated guinea pig gastric mucosa. TGF $\alpha / E G F$ receptor mRNA expression was also detected in the gastric mucosa of dogs and man in which cell enrichment was not performed (data not shown).

Samples of gastric mucosa were obtained from ten patients (Fig. 5, patients 2-11). These specimens contained matched tumor $(\mathrm{C})$ and adjacent uninvolved gastric mucosa $(\mathrm{N})$. The primary tumor sites were variable from the cardia to the pylorus, but the site did not appear to influence the level of TGF $\alpha$ expression (data not shown). An additional separate sample (No. 1) was obtained from mucosa adjacent to a benign gastric ulcer. Information regarding origin of these samples and histology is provided in Table I. Poly (A) RNA isolated

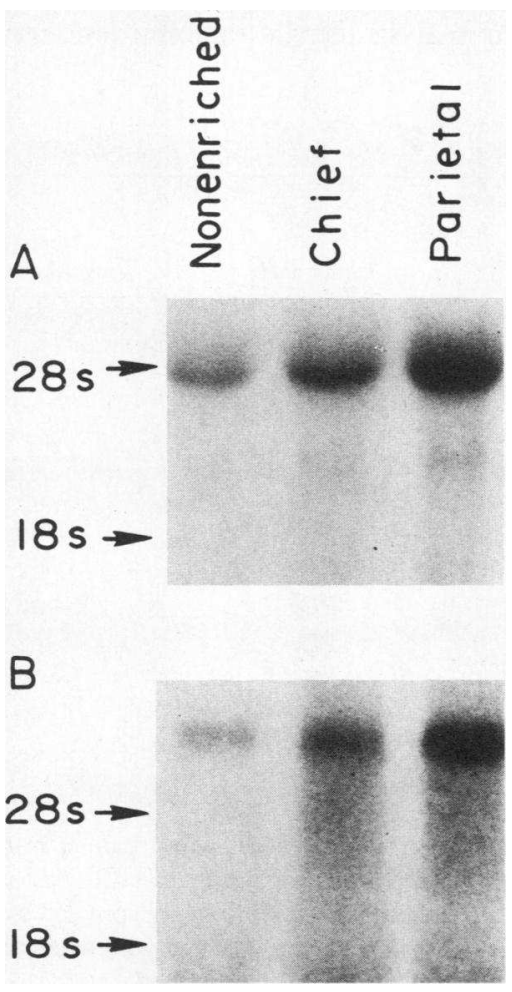

Figure 4. TGF $\alpha$ and TGF $\alpha /$ EGF receptor mRNA expression in guinea pig gastric mucosal cells. $20 \mu \mathrm{g}$ of total RNA from nonenriched gastric mucosal cells is compared with that from $95 \%$ enriched chief cell ( 20 $\mu \mathrm{g})$ and $65 \%$ enriched parietal cell fractions $(20 \mu \mathrm{g})$. In $A$, the blot was hybridized to the ${ }^{32}$ P-labeled TGF $\alpha$ probe; in $B$, the blot was hybridized to the ${ }^{32} \mathrm{P}$-labeled TGF $\alpha /$ EGF receptor probe. Equal loading was verified by observing ethidium bromide-stained ribosomal RNA bands on the gels. 


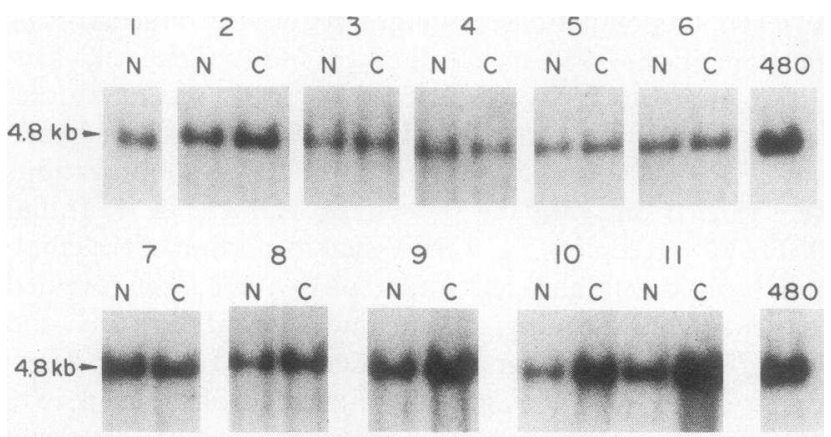

Figure 5. TGF $\alpha$ mRNA expression in gastric samples from 10 patients (2-11) with gastric carcinoma and a single patient (1) with benign gastric ulcer. $5 \mu \mathrm{g}$ of poly (A) RNA from the tumor $(C)$ and adjacent uninvolved gastric mucosa $(N)$ was hybridized with the ${ }^{32} \mathrm{P}$-labeled TGF $\alpha$ probe. Within each matched pair of RNA samples, equal loading has been verified by ribosomal RNA staining with ethidium bromide in the gels. $2 \mu \mathrm{g}$ of poly (A) RNA from SW 480 cells was used as a positive control for TGF $\alpha$ expression (41).

from all specimens showed TGF $\alpha$ expression. Visual inspection of an ethidium bromide-stained gel showed near-equal intensity of ribosomal RNA bands within the paired samples (data not shown). In four paired samples (Nos. 3, 4, 6, 7), there was no apparent increase in expression of TGF $\alpha$ mRNA in tumor compared to adjacent mucosa, but in patients $2,5,8,9$, 10 , and 11 there appeared to be an increase in TGF $\alpha$ expression in the tumor relative to the matched mucosa. All of the four tumor samples in which no increase of TGF $\alpha$ expression was seen compared to adjacent mucosa were histologically poorly differentiated tumors. Five of the six tumor samples that have increased TGF $\alpha$ expression relative to adjacent mucosa are either well or moderately differentiated on histological grading. Selected samples (Nos. 3, 6, 7, 9-11) were also processed for TGF $\alpha$ protein analysis using a radioimmunoassay kit and these data are presented in Table I. TGF $\alpha$ protein was detected in all samples and amounts were comparable among the samples; however, there was not a good correlation between intensity of TGF $\alpha$ mRNA signal and amounts of protein detected.

\section{Discussion}

TGF $\alpha$ and EGF may function in maintaining gastric mucosal integrity by promoting cell migration, stimulating cellular proliferation, and suppressing acid production. In support of this, epithelialization of experimentally induced gastric ulcers occurs at a rate faster than can be accounted for by mitosis (46) and rapid migration of gastric epithelial cells to cover the ulcer has been shown (47-49). TGF $\alpha$ and EGF stimulate a rapid migration of proliferating keratinocytes in culture which results in expansion of colony size at a rate faster than can be accounted for by mitosis (50). Furthermore, EGF promotes (by up to 100-fold) directed migration of cultured intestinal epithelial cells (51). In addition to its effects on cell migration, EGF (and presumably TGF $\alpha$ ) stimulate rat oxyntic gland DNA synthesis (15) and gastric mucosal growth $(18,52)$. Suppression of gastric acid secretion is another biological effect of EGF $(21,22,24)$. TGF $\alpha$ and EGF are equipotent in suppressing acid secretion from guinea pig gastric mucosa in vitro (28) and from rats in vivo (29). Our demonstration of expression of TGF $\alpha$ and its receptor throughout the gastric mucosa invites speculation that the local production of TGF $\alpha$ could mediate these effects and thus participate in the stomach's defense against mucosal injury by decreasing acid secretion, while simultaneously stimulating cell migration and later proliferation.

The highest level of TGF $\alpha$ expression is localized to the epithelial compartment of the stomach and very little or none is detected in the gastric submucosa. Our demonstration of increased TGF $\alpha$ and TGF $\alpha /$ EGF receptor mRNA expression

Table I.

\begin{tabular}{|c|c|c|c|c|c|c|}
\hline \multirow[b]{2}{*}{$\begin{array}{l}\text { Patient } \\
\text { no. }\end{array}$} & \multirow[b]{2}{*}{ Age } & \multirow[b]{2}{*}{ Tumor grade } & \multirow[b]{2}{*}{$\begin{array}{l}\text { Node } \\
\text { involvement }\end{array}$} & \multirow[b]{2}{*}{ Histology of adjacent mucosa } & \multicolumn{2}{|c|}{ TGF $\alpha$ protein } \\
\hline & & & & & $\mathbf{N}$ & $\mathrm{C}$ \\
\hline 1 & 45 & NA & NA & Normal & & \\
\hline 2 & 83 & WD & $1 / 22$ & $\begin{array}{l}\text { Focal intestinal metaplasia, } \\
\text { focal atrophy }\end{array}$ & & \\
\hline 3 & 61 & PD & $7 / 15$ & Unknown & 30.8 & 17.4 \\
\hline 4 & 33 & PD & $3 / 17$ & Focal intestinal metaplasia & & \\
\hline 5 & 77 & MD & $1 / 5$ & Unknown & & \\
\hline 6 & 73 & PD & $1 / 6$ & Unknown & 21.5 & 45.7 \\
\hline 7 & 70 & PD & None & Gastritis & 11.6 & 7.4 \\
\hline 8 & 59 & PD & $2 / 6$ & Unknown & & \\
\hline 9 & 73 & MD & None & Dysplasia & 17.4 & 15.9 \\
\hline 10 & 74 & MD & $1 / 64$ & Atrophic & 10.5 & 14.6 \\
\hline 11 & 58 & MD & None & Normal & 22.4 & 17.9 \\
\hline
\end{tabular}

Human patient samples analyzed for TGF $\alpha$ expression. Patient numbers correspond to the same numbers in Fig. 5 . All patients were males. The smallest tumor was $3.5 \times 1.5 \mathrm{~cm}$ and the largest was $12 \times 8.5 \times 6 \mathrm{~cm}$ in dimension. Protein content in tumor (C) or adjacent uninvolved mucosa $(\mathrm{N})$ is included for selected patients. Protein is expressed as nanograms of TGF $\alpha$ immunoreactive activity per milligram of extracted protein. Patient 1 had a benign gastric ulcer associated with a gastrocolic fistula. Abbreviations: NA, not applicable; WD, well differentiated; MD, moderately differentiated; PD, poorly differentiated. 
in parietal cell-enriched fractions from the guinea pig stomach, together with a preliminary description of specific TGF $\alpha / E G F$ binding sites on isolated canine parietal cells (53), support direct regulation of parietal cell acid secretion by TGF $\alpha$ as well as EGF. Thus, evidence is presented for a new pathway for modulation of gastric acid secretion, i.e., paracrine and/or autocrine regulation by locally produced TGF $\alpha$. The finding of TGF $\alpha$ and TGF $\alpha / E G F$ receptor expression in the chief cellenriched fraction is provocative since EGF has been reported to inhibit pepsinogen secretion in rabbit gastric mucosa (30).

In the dog, TGF $\alpha$ mRNA expression was greater in antral versus fundic mucosa. This observation was surprising in view of the high levels of TGF $\alpha$ mRNA expression in guinea pig parietal cells, which predominate in the fundus. One possible explanation for this paradoxical finding would be the presence of increased mRNA expression in cells found preferentially in the gastric antrum, perhaps the gastrin producing G-cell population (54). To assess expression of TGF $\alpha$ in canine G-cells, Northern blot analysis of a purified population of G-cells and/ or in situ hybridization studies will be required. The increased expression of TGF $\alpha$ in the dog antrum relative to fundus was not seen in the human samples. This may be a species difference, or may be due to the fact that the human samples were obtained from patients with gastric pathology.

Examination of the human samples suggests that there is a trend toward increased expression of TGF $\alpha$ mRNA in tumors compared to adjacent mucosa in those cases in which the tumors have a histological grade less than poorly differentiated, but the sample size is insufficient to draw firm conclusions. Like its mRNA, TGF $\alpha$ protein was detected in all samples examined, but there was not a good correlation between intensity of message and amount of protein. Possible explanations for this discrepancy include a variation in the site of sampling, transport, and excretion of TGF $\alpha$, or posttranscriptional regulation. TGF $\alpha$ species detected in cell extracts from various sources display heterogeneity in molecular weights, which may be due to the presence of larger $N$-glycosylated forms of TGF $\alpha$ that are released after proteolytic cleavage of the transmembrane TGF $\alpha$ precursor (55). The antibody used for the radioimmunoassay may not recognize these larger glycosylated forms and could lead to an underestimation of TGF $\alpha$ protein levels. What can be concluded with confidence is that TGF $\alpha$ mRNA and protein are present in human gastric carcinomas and adjacent noncancerous mucosa, the latter finding being consistent with results obtained from normal gastric mucosa of the other mammalian species in the present study. Clearly, TGF $\alpha$ expression is not restricted to neoplastic tissue.

Whereas TGF $\alpha$ mRNA expression was detected in gastric mucosa from all four species studied, weak EGF mRNA expression was detected in the fundic mucosa of the dog only. The explanation for this species difference and regional distribution of EGF expression within the dog gastric mucosa is not apparent. Previous studies have shown EGF immunoreactivity in the human gastric mucosa (56). We did not detect EGF mRNA in human gastric mucosa from surgically resected tissue; however, these samples were adjacent to a tumor or a benign ulcer and may not be representative of normal healthy mucosa. The samples from guinea pig, rat, and dog, however, do represent healthy mammalian gastric mucosa. If there is little or no EGF mRNA and consequently little or no protein produced in the gastric mucosa, then what has been detected in the past by immunological methods $(18,56)$ may be produced more proximally in the alimentary tract. For example, swallowed EGF secreted from the salivary glands may become bound to gastric mucosal cell receptors, internalized, and thus detected as immunoreactivity.

The present study demonstrates expression of TGF $\alpha$ and its receptor throughout the gastric mucosa in four mammalian species, including man. These observations, when coupled to described actions of EGF and TGF $\alpha$, implicate locally produced TGF $\alpha$ in regulation of gastric acid secretion and in cell renewal after injury to the gastric mucosa.

\section{Acknowledgments}

The authors thank Regina Dennis for typing the manuscript and Jed Rifkin for critically reviewing the manuscript, Dr. Susan Halter for reviewing the histology, and Dr. Mark Pittelkow for providing tissues from the Mayo Clinic. We also thank Dr. Harold L. Moses and Dr. Basil Hirschowitz for helpful discussions. This work was supported in part by U. S. Public Health Service grant No. CA 46413, ACS CD-367 (Dr. Coffey), and the Veterans Administration (Dr. Cherner and Dr. Coffey). Dr. Coffey is the recipient of a Research Associate Award under the Career Development Program of the Veterans Administration. Dr. Beauchamp is supported by a Physician Scientist Award CA-01309. Dr. Barnard is supported by an American Gastroenterological Association/Pharmacia Scholar Award.

Note added in proof. Since submission, two papers have reported TGF $\alpha$ mRNA expression in human benign and malignant gastric tissues $(57,58)$.

\section{References}

1. Marquardt, H., M. M. Hunkapiller, L. E. Hood, and G. J. Todaro. 1984. Rat transforming growth factor type 1: structure and relation to epidermal growth factor. Science (Wash. DC). 223:1079-1082.

2. Derynck, R., A. B. Roberts, M. E. Winkler, E. Y. Chen, and D. V. Goeddel. 1984. Human transforming growth factor- $\alpha$ : precursor structure and expression in E. coli. Cell. 38:287-297.

3. Todaro, G. J., C. Fryling, and J. E. DeLarco. 1980. Transforming growth factors produced by certain human tumor cells: polypeptides that interact with epidermal growth factor receptors. Proc. Natl. Acad. Sci. USA. 77:5258-5262.

4. Massague, J. 1983. Epidermal growth factor-like transforming growth factor. J. Biol. Chem. 258:13614-13620.

5. Carpenter, G., C. M. Stoscheck, Y. A. Preston, and J. E. DeLarco. 1983. Antibodies to the epidermal growth factor receptor block the biological activities of sarcoma growth factor. Proc. Natl. Acad. Sci. USA. 80:5627-6530.

6. Twardzik, D. R., J. E. Ranchalis, and G. J. Todaro. 1982. Mouse embryonic transforming growth factors related to those isolated from tumor cells. Cancer Res. 42:590-593.

7. Samsoondar, J., M. S. Kobrin, and J. E. Kudlow. 1986. $\alpha$-transforming growth factor secreted by untransformed bovine anterior pituitary cells in culture. J. Biol. Chem. 261:14408-14413.

8. Coffey, R. J., R. Derynck, J. N. Wilcox, T. S. Bringman, A. S. Goustin, H. L. Moses, and M. R. Pittelkow. 1987. Production and auto-induction of transforming growth factor- $\alpha$ in human keratinocytes. Nature (Lond.). 328:817-820.

9. Coffey, R. J., N. J. Sipes, C. C. Bascom, R. G. Deal, C. Y. Pennington, B. E. Weissman, and H. L. Moses. 1988. Growth modulation of mouse keratinocytes by transforming growth factors. Cancer Res. 48:1596-1602. 
10. Schreiber, A. B., M. E. Winkler, and R. Derynck. 1986. Transforming growth factor- $\alpha$ : a more potent angiogenic mediator than epidermal growth factor. Science (Wash. DC). 232:1250-1253.

11. Derynck, R. 1986. Transforming growth factor- $\alpha$ : structure and biological activities. J. Cell Biol. 32:293-304.

12. Derynck, R. 1988. Transforming Growth Factor- $\alpha$. Cell. 54:593-595.

13. Beauchamp, R. D. and J. C. Thompson. 1987. Actions of Gut Peptides. In Gastrointestinal Endocrinology. J. C. Thompson, G. H. Greeley, P. L. Rayford, and C. M. Townsend, editors. McGraw-Hill Book Co., New York. 91-108.

14. Dembinski, A., H. Gregory, S. J. Konturek, and M. Polanski. 1982. Trophic action of epidermal growth factor on the pancreas and gastroduodenal mucosa in rats. J. Physiol. 325:35-42.

15. Johnson, L. R., and P. D. Guthrie. 1980. Stimulation of rat oxyntic gland mucosal growth by epidermal growth factor. Am. J. Physiol. 238:G45-49.

16. Konturek, S. J., T. Radecki, T. Brzozowski, I. Piastucki, A. Dembinski, A. Dembinska-Kiec, A. Zmuda, R. Gryglewski, and H. Gregory. 1981. Gastric cytoprotection by epidermal growth factor. Gastroenterology. 81:438-443.

17. Skinner, K. A., B. D. Soper, and B. L. Tepperman. 1984. Effect of sialoadenectomy and salivary gland extracts on gastrointestinal mucosal growth and gastrin levels in the rat. J. Physiol. 351:1-12.

18. Konturek, S. J., A. Dembinski, Z. Warzecha, T. Brzozowski, and H. Gregory. 1988. Role of epidermal growth factor in healing of chronic gastroduodenal ulcers in rats. Gastroenterology. 94:13001307.

19. Roberts, A. B., L. C. Lamb, D. L. Newton, M. B. Sporn, J. E. DeLarco, and G. J. Todaro. 1980. Transforming growth factors: Isolation of polypeptides from virally and chemically transformed cells by acid/ethanol extraction. Proc. Natl. Acad. Sci. USA. 77:3494-3498.

20. Cohen, S., and G. Carpenter. 1975. Human epidermal growth factor: Isolation and chemical and biological properties. Proc. Natl. Acad. Sci. USA. 72:1317-1321.

21. Culmer, C. U., A. J. Atkinson, and A. C. Ivy. 1939. Depression of gastric secretion by the anterior pituitary-like fraction of pregnancy urine. Endocrinology. 24:631-637.

22. Gray, J. S., Wieczorowski, and A. C. Ivy. 1939. Inhibition of gastric secretion by extracts of normal male urine. Science (Wash. DC). 89:(2317)489-490.

23. Starkey, R. H., S. Cohen, and D. N. Orth. 1975. Epidermal growth factor: Identification of a new hormone in human urine. Science (Wash. DC). 189:800-802.

24. Gregory, H. 1975. Isolation and structure of urogastrone and its relationship to epidermal growth factor. Nature (Lond.). 257:325-327.

25. Konturek, S. J., M. Cieszkowski, J. Jaworek, J. Konturek, T. Brzozowski, and H. Gregory. 1984. Effects of epidermal growth factor on gastrointestinal secretions. Am. J. Physiol. 246:G580-G586.

26. Gonzalez, A., I. Garrido, and I. D. Vial 1981. Epidermal growth factor inhibits cytoskeleton-related changes in the surface of parietal cells. J. Cell Biol. 88:108-114.

27. Finke, U., M. Rutten, R. A. Murphy, and W. Silen. 1985. Effects of epidermal growth factor on acid secretion from guinea pig gastric mucosa: In vitro analysis. Gastroenterology. 88:1175-1182.

28. Rhodes, J. A., J. P. Tam, U. Finke, M. Saunders, J. Bernanke, W. Silen, and R. A. Murphy. 1986. Transforming growth factor- $\alpha$ inhibits secretion of gastric acid. Proc. Natl. Acad. Sci. USA. 83:38443846.

29. Gregory, H., C. E. Thomas, J. A. Young, I. R. Willshire, and A. Garner. 1988. The contribution of the C-terminal undecapeptide sequence of urogastrone-epidermal growth factor to its biological action. Regul. Peptides. 22:217-226.

30. Miyamoto, T., M. Itoh, Y. Yokoyama, S. Imai, T. Joh, Y. Noguchi and T. Takeuchi. 1987. Inhibitory effect of epidermal growth factor for pepsinogen secretion in rabbit gastric mucosa. Gastroenterology. 92:1537. (Abstr.)

31. Forgue-Lafitte, M. E., I. Kobari, C. Gespach, M. C. Chamblier, and G. Rosselin. 1984. Characterization and repartition of epidermal growth factor-urogastrone receptors in gastric glands isolated from young and adult guinea pigs. Biochim. Biophys. Acta. 798:192-198.

32. Skinner, M. K., and R. J. Coffey. 1988. Regulation of ovarian cell growth through the local production of transforming growth factor- $\alpha$ by theca cells. Endocrinology. 123:2632-2638.

33. Skinner, M. K., K. Takacs, and R. J. Coffey. 1989. Transforming growth factor- $\alpha$ gene expression and action in the seminiferous tubule: peritubular cell-sertoli cell interactions. Endocrinology. 124:845-854.

34. Raufman, J.-P., V. E., Sutliff, D. H. Kasbekar, R. T. Jensen, and J. D. Gardner 1984. Pepsinogen secretion from dispersed chief cells from guinea pig stomach. Am. J. Physiol. 247:G95-G104.

35. Frazier, M. L., W. Mars, D. L. Florine, R. A. Montagna, and G. F. Saunders. 1983. Efficient extraction of RNA from mammalian tissue. Mol. Cell. Biol. 56:113-122.

36. MacDonald, R. J., G. H. Swift, A. E. Przybyla, and J. M. Chirgwin. 1987. Isolation of RNA using guanidinium salts. Methods Enzymol. 152:219-227.

37. Dobner, P. R., E. S. Kawasaki, L. Yu, and F. C. Bancroft. 1981. Thyroid or glucocorticoid hormone induces pre-growth-hormone mRNA and its probable nuclear precursor in rat pituitary cells. Proc. Natl. Acad. Sci. USA. 78:2230-2234.

38. Thomas, P. S. 1980. Hybridization of denatured RNA and small DNA fragments transferred to nitrocellulose. Proc. Natl. Acad. Sci. USA. 77:5201-5205.

39. Simmen, F. A., M. L. Gope, T. Z. Schulz, D. A. Wright, G. Carpenter, and B. W. O'Malley. 1984. Isolation of an evolutionarily conserved epidermal growth factor receptor cDNA from human A431 carcinoma cells. Biochem. Biophys. Res. Commun. 124:125-132.

40. Melton, D. A., D. A. Krieg, M. R. Rebagliati, T. Maniatis, K. Zinn, and M. R. Green. 1984. Efficient in vitro synthesis of biologically active RNA and RNA hybridization probes from plasmids containing a bacteriophage sp6 promoter. Nucleic Acids Res. 12:7035-7056.

41. Coffey, R. J., A. S. Goustin, A. M. Soderquist, G. D. Shipley, J. Wolfshohl, G. Carpenter, and H. L. Moses. 1987. Transforming growth factor $\alpha$ and $\beta$ expression in human colon cancer lines: implications for an autocrine model. Cancer Res. 47:4590-4594.

42. Bell, G. I., N. M. Fong, M. M. Stemplien, M. A. Wormsted, D. Caput, K. Lailing, M. S. Urdea, L. B. Rall, and R. Samchez-Pescador. 1986. Human epidermal growth factor precursor: cDNA sequence, expression in vitro and gene organization. Nucleic Acids Res. 14:8427-8446.

43. Taylor, J. M., R. Illmensee, and J. Summers. 1976. Efficient transcription of RNA into DNA by avian sarcoma virus polymerase. Biochim. Biophys. Acta. 442:324-330.

44. Danielson, P. E., S. Forss-Petter, M. A. Brow, L. Calavetta, J. Douglass, R. J. Milner, and J. G. Sutcliffe. 1988. p1 B15: a cDNA clone of the rat mRNA encoding cyclophilin. DNA. 7:261-267.

45. Bradford, M. M. 1976. A rapid and sensitive method for the quantitation of microgram quantities of protein utilizing the principle of protein-dye binding. Anal. Biol. 72:248-254.

46. Hingson, D. J., and S. Ito. 1971. Effect of aspirin and related compounds on the fine structure of mouse gastric mucosa. Gastroenterology. 61:156-177.

47. Yeomans, N. D., D. J. B. St. John, and W. G. R. M. de Boer. 1973. Regeneration of gastric mucosa after aspirin-induced injury in the rat. Dig. Dis. Sci. 18:773-780.

48. Svanes, K., S. Ito, K. Takeuchi, and W. Silen. 1982. Restitution of the surface epithelium of the in vitro frog gastric mucosa after damage with hyperosmolar sodium chloride. Gastroenterology. 82:1409-1426.

49. Critchlow, J., D. Magee, S. Ito, K. Takeuchi, and W. Silen. 
1985. Requirements for restitution of the surface epithelium of frog stomach after mucosal injury. Gastroenterology. 88:237-249.

50. Barrandon, Y., and H. Green. 1987. Cell migration is essential for sustained growth of keratinocyte colonies: The roles of transforming growth factor- $\alpha$ and epidermal growth factor. Cell. 50:1131-1137.

51. Blay, J., and K. D. Brown. 1985. Epidermal growth factor promotes the chemotactic migration of cultured rat intestinal epithelial cells. J. Cell. Physiol. 124:107-112.

52. Konturek, S. J., T. Brzozowski, I. Piastucki, A. Dembinski, T. Radecki, A. Dembinska-kiec, A. Zmuda, and H. Gregory. 1981. Role of mucosal prostaglandins and DNA synthesis in gastric cytoprotection by luminal epidermal growth factor. Gut. 22:927-932.

53. Chen, M. C., D. A. Amirian, and A. H. Soll. 1984. Epidermal growth factor (EGF) binding and inhibitory effect on acid secretion on isolated canine parietal cells. Fed. Proc. 43:1073. (Abstr.)

54. Solcia, E., C. Capella, R. Buffa, R. U. Luciana, R. Fiocca, and F. Sessa. 1987. Endocrine cells of the digestive system. In Physiology of the Gastrointestinal Tract. L. R. Johnson, editor. Raven Press, New York. 111-130.

55. Bringman, T. S., P. B. Lindquist, and R. Derynck. 1987. Different transforming growth factor- $\alpha$ species are derived from a glycosylated and palmitoylated transmembrane precursor. Cell. 48:429440.

56. Kasselberg, A. G., D. N. Orth, M. E. Gray, and M. T. Stahlman. 1985. Immunocytochemical localization of human epidermal growth factor/urogastrone in several human tissues. J. Histol. Cytotol. 33:315-322.

57. Malden, L. T., U. Novak, and A. W. Burgess. 1989. Expression of transforming growth factor alpha messenger RNA in the normal and neoplastic gastro-intestinal tract. Int. J. Cancer. 43:380-384.

58. Bennett, C., I. M. Paterson, C. M. Corbishley, and Y. A. Luqmani. 1989. Expression of growth factor and epidermal growth factor receptor encoded transcript in human gastric tissues. Cancer Res. 49:2104-2111. 